\title{
Inguinal hernia repair: can one identify the three main nerves of the region?
}

\section{Herniorrafia inguinal: pode-se identificar os três principais nervos da região?}

João Vicente Machado Grossi, AsCBC-RS'; ' Leandro Tottı Cavazzola, TCBC-RS²; Ricardo Breigeiron TCBC-RS³

\begin{abstract}
A B S T R A C T
Objective: To identify the nerves in the groin during inguinal hernia repair by inguinotomy. Methods: We conducted a prospective, sequenced, non-randomized study comprising 38 patients undergoing inguinal hernia repair with placement of polypropylene mesh. Results: The male patients were $36(94.7 \%)$, with a mean age and standard deviation of $43.1 \pm 14.5$, body mass index of $24.4 \pm$ 2.8. Comorbidities were hypertension in two (5.2\%), smoking in $12(31.5 \%)$ and obesity in two (5.2\%). The hernia was located only on the right in $21(55.2 \%)$ patients, only on the left in $11(28.9 \%)$, and was bilateral in six $(15.7 \%)$ patients. Prior hernia repair was present in seven (18.4\%) patients. The identification of the three nerves during operation was made in 20 (52.6\%) patients, the ilioinguinal nerve and the iliohypogastric nerve were identified in $33(86.8 \%)$, and the genital nerve branch of the genitofemoral nerve, in 20 (52.6\%). Resection of at least one of the nerves was performed in seven (18.4\%) cases, two iliohypogastric nerves and five ilioinguinal nerves. The average operating time was $70.8 \pm 18.2$ minutes. The hospital stay was $1.42 \pm 1.18$ days. Ten patients (26.3\%) returned to physical activity around the first postoperative visit, and 37 (97.3\%) in the last. The follow-up time was $95.6 \pm$ 23.5 days. The inability to identify the ilioinguinal nerve was associated with previous repair $(p=0.035)$. Conclusion: The identification of the three nerves during inguinal hernia surgery has been described in more than half of the cases and prior repair interfered with the identification of ilioinguinal nerve.
\end{abstract}

Key words: Inguinal Hernia. Hernia repair. Peripheral Nerves. Chronic Pain / surgery. Neuralgia / surgery.

\section{INTRODUCTION}

$\mathrm{H}^{\mathrm{s}}$ ernias correspond to total or partial protrusion of an organ contained in a sac of peritoneal lining outside of the abdominal wall through a musculo-aponeurotic defect ${ }^{1-3}$. They may occur at various positions: umbilical $(10 \%)$, epigastric $(6 \%)$, incisional $(10 \%)$, femoral $(5 \%)$ or inguinal $(69 \%)^{1,4}$.

The only way to treat hernias is through hernioplasty ${ }^{5}$. There are numerous techniques for the surgical repair of abdominal wall defects and they have evolved in recent years. Basically, they are divided into techniques that use only primary aponeurotic suture - which must be free of tension - and techniques using synthetic prostheses (meshes) 6 .

The repair of inguinal hernias carried out through with a mesh and tension-free surgical technique, introduced in 1989 by Lichtenstein, is widely used and presents growing popularity among surgeons ${ }^{7}$. Some studies showed that the techniques that use the patient's own tissue for hernial repair exhibit a relapse of 10 to $50 \%$, while the use of prostheses reduces relapse to 3 to $17 \%{ }^{8,9}$. In the United States, more than $90 \%$ of patients with abdominal wall hernias are subjected to correction with the use of prosthetic materials. Worldwide, it is estimated that one million such implants are used annually ${ }^{6}$. Despite the popularity and increased use of polypropylene mesh in hernioplasties, there are numerous complications arising from its use. Due to the mesh's large penetration capacity when in contact with intraperitoneal viscera, complications can occur such as adhesions, fibrosis, chronic pain, fistula and intestinal obstruction. Therefore, its contact with intra-abdominal organs is not recommended ${ }^{4}$.

Chronic pain (inguinodinia) is an important postoperative complication and is associated with neural tissue damage during the operation, as well as with the healing process produced by the suture or the mesh itself. Such complications negatively impact the patient's quality of life. The identification and preservation of all three groin nerves - nerve ilioinguinal, iliohypogastric and the genital branch of the genitofemoral - during hernia correction by the open technique reduces the risk of chronic pain.

This study aims to identify the groin nerves during inguinal hernia repair by inguinotomy.

1. Disciplina de Clínica Cirúrgica do Adulto I, Faculdade de Medicina de Barbacena - MG - Brazil; 2. Faculdade de Medicina, Universidade Federal de Minas Gerais (UFMG) - MG - Brazil; 3. Serviço de Cirurgia Geral e do Trauma no Hospital de Pronto Socorro (HPS) de Porto Alegre - RS - Brazil. 


\section{METHODS}

This was a prospective, sequenced, nonrandomized study. The sample consisted of 38 patients who underwent hernia repair with polypropylene mesh placement and were evaluated during 12 months.

This study was approved by the Comitê de Ética da Prefeitura Municipal de Porto Alegre, under the registration number 001.031967.12.4. All patients were informed of the survey by informed consent. All procedures were supervised by a responsible medical preceptor.

The study examined the identification of nerves in the groin during inguinal hernia repair procedure, primary or recurrent, by the Lichtenstein technique. We used the Nyhus classification ${ }^{10}$ to categorize the hernias.

We evaluated the following patients data: gender, age, body mass index (BMI) and associated comorbidities, including hypertension (SAH), smoking and obesity. We also considered in the analysis: the location of the hernia, the previous repair, the length of stay, type of daily physical activity, the return to work activities, the followup and surgical indication (emergency or elective). After the procedure, all patients were transferred to the recovery room with standard analgesia (dipyrone $1 \mathrm{~g} \mathrm{EV} \mathrm{6/6h} \mathrm{+}$ morphine $4 \mathrm{mg} 4 / 4 \mathrm{~h}$, in case of strong pain). After the surgery, the description of the technique was filled according to the nerve identification protocol. In the immediate postoperative period, the patient was discharged the next day with recommendations established by the institution and outpatient return in seven days, accompanied by three more consultations. If patients did not refer pain during the postoperative evaluation in 90 days, they were released from monitoring. Should they have any symptoms, they remained in follow-up until the sixth postoperative month.

Statistical analysis was described by mean and standard deviation for quantitative variables. The qualitative variables were described by absolute and relative frequencies. Association between variables was evaluated by the Pearson's chi-square test or Fisher's exact test. The residues adjusted test was used to complement the associations with polytomic variables. The significance level was $5 \%(p<0.05)$.

\section{RESULTS}

All patients could be evaluated in the proposed period. Upon characterization of the sample there was a predominance of male patients, $36(94.7 \%)$, with a mean age and standard deviation of $43.1 \pm 14.5$ years. The body mass index (BMI) was $24.4 \pm 2.8 \mathrm{~kg} / \mathrm{m}^{2}$, and obesity (BMl> $30 \mathrm{~kg} / \mathrm{m}^{2}$ ) was present in only two patients $(5.2 \%)$.

The most prevalent type of daily physical activity was laborer, with 26 (68.4\%), followed by administrative, with eight (21.1\%). Two (5.2\%) patients were athletes, one $(2.6 \%)$ had physical disabilities and one (2.6\%) was retired. The associated comorbidities identify were systemic arterial hypertension (SAH) in two (5.2\%), alcoholism in one $(2.6 \%)$, smoking in $12(31.5 \%)$ and benign prostatic hyperplasia in one (2.6\%). Twenty-two (57.9\%) patients were healthy.

The positioning of hernias was divided into right only, $21(63.2 \%)$ patients, only on the left, $11(36.8 \%)$ and bilateral, six (15.7\%). Seven patients had previous repair, considered recurrent hernia, with the following techniques distribution: Bassini in one patient Shouldice in three, Lichtenstein in one and other techniques not identified during repair in two. Elective surgery was the most accomplished, with 31 (81.6\%), and urgency, in seven (18.4\%). The classification of the American Society of Anesthesiologists (ASA) was I in 29 (76.3\%) and II in the remaining, not being performed surgeries in patients classified as ASA III and IV. Spinal anesthesia was performed in $36(94.7 \%)$ and only two patients needed general anesthesia due to prolonged surgical time and intraoperative bleeding. The associated procedures were orchiectomy $(n=1,2.6 \%)$ and cord cyst excision $(n=1,2.6 \%)$.

Regarding the identification of nerves in the inguinal region during the procedure, the ilioinguinal nerve was identified in $20(52.6 \%)$ patients, the iliohypogastric in $33(86.8 \%)$ and the genital nerve branch of the genitofemoral in 20 (52.6\%) patients (Figure 1).

Resection of at least one nerve was performed in seven (18.4\%) patients due to technical difficulties, in two cases the iliohypogastric and in five, the ilioinguinal. The average operating time was $70.8 \pm 18.2$ minutes. The completion of the procedure was performed by a first-year resident in $21(55.3 \%)$ cases and by a second-year one in $17(44.7 \%)$. As a main auxiliary, $21(55.3 \%)$ cases were made by a resident of the first year, 16 by a second-year and one by a medical school graduate.

As for the Nyhus classification, type 3a was predominant, with 17 (44.7\%) patients, followed by type 2 in nine $(23.6 \%)$, type 4 in seven (18.4\%), type $3 \mathrm{~b}$ in three

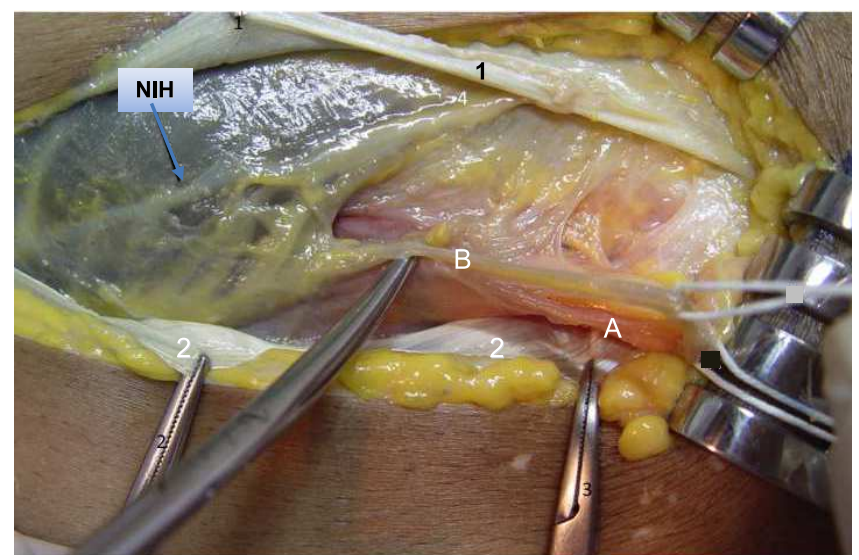

Figure 1 - Identification of inguinal nerves.

A- inguinal cord; $B$ - liioinguinal nerve; IHN- iliohypogastric nerve; 1) aponeurosis of the external oblique muscle; 2) Inguinal ligament. 
(7.8\%) and the types 1 and 3c each with one patient (2.6\%) (Table 1).

The most commonly used mesh was the polypropylene one, with medium weight $\left(65 \mathrm{mg} / \mathrm{cm}^{3}\right)$, in $36(94.7 \%)$ patients. The remaining patients had the heavy weight polypropylene mesh $\left(99 \mathrm{mg} / \mathrm{cm}^{3}\right)$ implanted.

After the surgical procedure there were no complications in 32 (84.2\%) patients. Hematoma occurred in five patients and seroma in one. The mean and standard deviation of hospital stay was $1.42 \pm 1.18$ in days, with 30 (79\%) patients staying overnight, and more than 24 hours in only eight $(21.1 \%)$ cases. As regards the personal response to surgery, in the first outpatient (seventh day after surgery) 24 (63.2\%) patients answered that there was a significant improvement, $13(34.2 \%)$ said that there was some improvement and one $(2.6 \%)$, that there was no change.

Ten $(26.3 \%)$ patients had returned to physical activity by their first visit, whereas 37 (97.4\%) had returned by the last visit. The mean follow-up time was $95.6 \pm 23.5$ days.

When assessing the type of surgical indication, the identification of nerves in the inguinal region of the anterior wall did not show statistically significant differences between elective or emergency procedures. Although not statistically significant, the identification of the genital branch of genitofemoral nerve was lower in emergency operations, $(p=0.222$, Table 2$)$.

Prior repair - recurrent hernia - had an increased operative time and also showed statistically significant association in not identifying the ilioinguinal nerve (Table3).

\section{DISCUSSION}

There was no need to exclude any patient. It was possible to monitor all patients for at least 90 days after surgery. The identification did not change operating time or required some special training. Thus, the study was feasible and reproducible, even in emergency procedures.

The sample's associated comorbidities found in this study were in only two patients with obesity criteria, which could contribute to greater technical difficulty and decreased nerves identification. Another comorbidity, such as smoking, prevalent in the sample, is a characteristic that can be modified. Cigarette smoking increases the risk of herniation development and, consequently, local symptoms increase, increasing the risk of turning an elective procedure into an emergency one ${ }^{11}$.

The percentage of identification of the three nerves during the procedure was $52.6 \%$, whereas the highest index described in publications is only $36 \%$. The identification of the ilioinguinal and iliohypogastric nerves was $86.8 \%$ in our sample. The literature shows a tendency to identify the ilioinguinal nerve around $70 \%$, and the iliohypogastric, of $59 \%$. This difference can be explained by the active search and identification of nerves during the procedure. Regarding the genital branch of the genitofemoral, we found in $56.2 \%$ of cases, corroborating the results from the literature, of $55.6 \% 12,13$.

The identification of nerves following the anatomical description of the order of appearance on the

Table 1 - Distribution of patients according to the Nyhus classification ${ }^{10}$

\begin{tabular}{lr}
\hline NYHUS & Patients / Percentage \\
\hline Type 1 & $1 / 2.6 \%$ \\
Type 2 & $9 / 23.6 \%$ \\
Type 3a & $17 / 44.7 \%$ \\
Type 3b & $3 / 7.8 \%$ \\
Type 3c & $1 / 2.6 \%$ \\
Type 4 & $7 / 18.4 \%$ \\
Total & $38 / 100 \%$ \\
\hline
\end{tabular}

Table 2 - Identification of nerves in the inguinal region during hernia repair and its association with the type of surgical indication.

\begin{tabular}{|c|c|c|c|}
\hline Variables & $\begin{array}{c}\text { Emergency surgery } \\
\mathrm{n}(\%)\end{array}$ & $\begin{array}{c}\text { Elective surgery } \\
n(\%)\end{array}$ & $P$ \\
\hline liioinguinal nerve & & & $1.000 *$ \\
\hline Yes & $6 \quad(85.7)$ & $27 \quad(87.1)$ & \\
\hline No & $1 \quad(14.3)$ & $4 \quad(12.9)$ & \\
\hline Iliohypogastric nerve & & & $1.000 *$ \\
\hline Yes & $6 \quad(85.7)$ & $27 \quad(87.1)$ & \\
\hline No & $1 \quad(14.3)$ & $4 \quad(12.9)$ & \\
\hline Genital branch of GF & & & $0.222 *$ \\
\hline Yes & $2 \quad(28.6)$ & $18 \quad(58.1)$ & \\
\hline No & $5 \quad(71.4)$ & $13 \quad(41.9)$ & \\
\hline
\end{tabular}

* Fisher's exact test.

GF= genitofemoral nerve. 
Table 3 - Type of operation with identification of groin nerves during hernia repair.

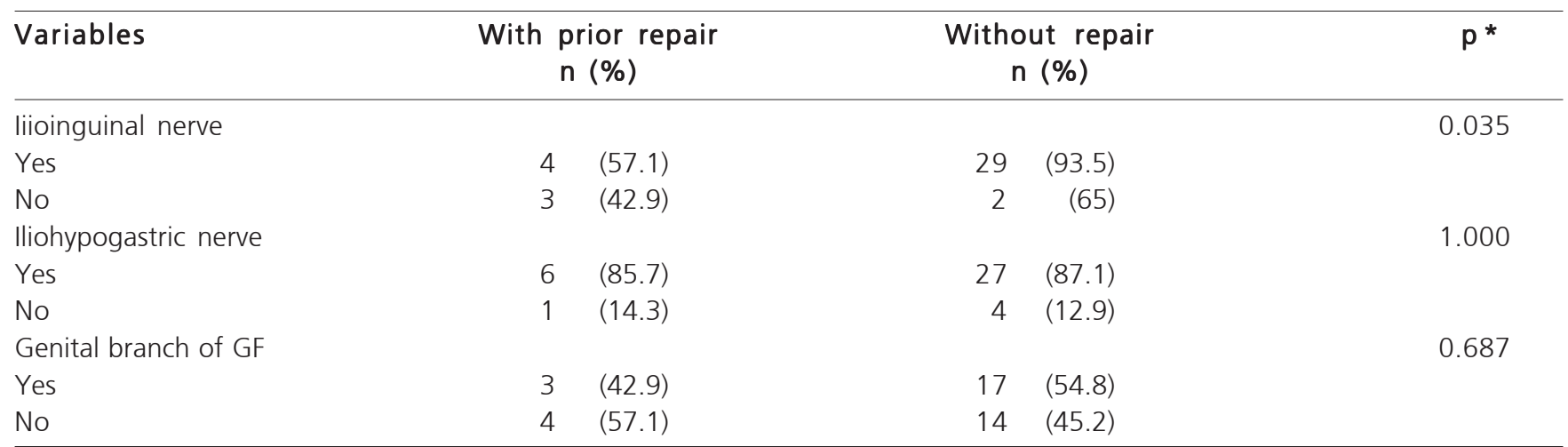

* Fisher's exact test.

$G F=$ genitofemoral nerve.

operation steps would have a higher rate of findings, with consequent correct identification of the groin nerves. However, when faced with a non-virgin area recurrent hernia - or with a mesh already integrated to the tissue, one has a lower chance of isolating the nerves. In this sample, recurrent hernia showed a statistically significant difference in not identify the ilioinguinal nerve ${ }^{13}$.

Even with training residents, it was possible to identify the three nerves in the inguinal region in more than half of cases. The study of the inguinal region and its anatomy should be part of the learning program and subsequent formation of new surgeons as a prevention of adverse effects of the procedure ${ }^{14}$.

Even with the use of new techniques such as the use of PHS mesh, one can used the nerves identification to monitor cases of chronic pain or numbness associated with the procedure ${ }^{15}$.

In conclusion, the identification of the three nerves during inguinal hernia surgery has been reported in over half of cases, and the prior repair interfered with the identification of ilioinguinal nerve.

\title{
RE S U M O
}

\begin{abstract}
Objetivo: identificar os nervos da região inguinal durante hernioplastia inguinal por inguinotomia. Métodos: estudo prospectivo, sequenciado, não randomizado, composto por 38 pacientes submetidos à herniorrafia inguinal com colocação de tela de polipropileno. Resultados: Os pacientes masculinos eram 36 (94,7\%), com média de idade e desvio-padrão de 43,1 \pm 14,5, índice de massa corporal de 24,4 $\pm 2,8$. As comorbidades eram HAS em dois (5,2\%), tabagismo em 12 (31,5\%) e obesidade em dois (5,2\%). A hérnia localizava-se somente à direita em 21 (55,2\%) pacientes, somente à esquerda em 11 (28,9\%), e era bilateral em seis (15,7\%) pacientes. O reparo prévio da hérnia foi feito em sete $(18,4 \%)$ pacientes. A identificação dos três nervos durante a operação fezse em 20 (52,6\%) pacientes, o nervo ílio-inguinal e o nervo ílio-hipogástrico foram identificados em 33 (86,8\%), e o ramo genital do nervo gênito-femoral em 20 (52,6\%). A ressecção de ao menos um dos nervos foi realizada em sete (18,4\%), sendo dois nervos íliohipogástricos e cinco nervos ílio-inguinais. O tempo médio de operação foi 70,8 $\pm 18,2$ minutos. O tempo de internação hospitalar foi $1,42 \pm 1,18$ dias. Retornaram à atividade física no primeiro atendimento dez (26,3\%) pacientes e, no último, 37 (97,3\%). O tempo de acompanhamento foi 95,6 \pm 23,5 dias. A impossibilidade de identificação do nervo ílio-inguinal associou-se ao reparo prévio $(p=0,035)$. Conclusão: a identificação dos três nervos durante a hernioplastia inguinal foi descrito em mais da metade dos casos e o reparo prévio interferiu na identificação do nervo ílio inguinal.
\end{abstract}

Descritores: Hérnia Inguinal. Herniorrafia. Nervos Periféricos. Dor Crônica/cirurgia. Neuralgia/cirurgia.

\section{REFERENCES}

1. Dabbas N, Adams K, Pearson K, Royle G. Frequency of abdominal wall hernias: is classical teaching out of date? JRSM Short Rep. 2011;2(1):5.

2. Lambert B, Manna BB, Montes JHM, Bigolin AV, Grossi JVM, Cavazzola LT. Does collagen-coated polyester mesh decrease teh rate of intraperitoneal adhesions in incisional hérnia repair? Bras J Video-Sur. 2012:5(1):37-43.

3. LeBlanc KA, Bellanger D, Rhynes KV 5th, Baker DG, Stout RW. Tissue attachment strength of prosthetic meshes used in ventral and incisional hernia repair. A study in the New Zeland White rabbit adhesion model. Surg Endosc. 2002;16(11):1542-6.

4. Puttini SMB. Avaliação da resposta inflamatória desencadeada pelas telas de polipropileno e politetrafluoretileno expandido im- 
plantadas no espaço intraperitoneal. Estudo experimental em camundongos [dissertação]. Brasília, DF: Universidade de Brasília, Faculdade de Medicina; 2006.

5. Demir U, Mihmanli M, Coskun H, Dilege E, Kalyoncu A, Altinli E, et al. Comparison of prosthetic materials in incisional hernia repair. Surg Today. 2005;35(3):223-7.

6. N N, R S. A comparative study between modified Bassini's repair and Lichtenstein mesh repair (LMR) of inguinal hernias in rural population. J Clin Diagn Res. 2014;8(2):88-91.

7. Mizrahi H, Parker MC. Management of asymptomatic inguinal hernia: a systematic review of the evidence. Arch Surg. 2012;147(3):277-81.

8. Seiler C, Baumann P, Kienle P, Kuthe A, Kuhlgatz J, Engemann R, et al. A randomised, multi-centre, prospective, double blind pilotstudy to evaluate safety and efficacy of the non-absorbable Optilene Mesh Elastic versus the partly absorbable Ultrapro Mesh for incisional hernia repair. BMC Surg. 2010;10:21.

9. Pundek MRZ, Czeczko NG, Yamamoto CT, Pizzatto RF, Czeczko LEA, Dietz UA, et al. Estudo das telas cirúrgicas de polipropileno/ poliglecaprone e de polipropileno/polidioxanona/celulose oxidada regenerada na cicatrização de defeito produzido na parede abdominal em ratos. ABCD, arq bras cir dig. 2010:23(2) 94-9.

10. Nyhus LM, Klein MS, Rogers FB. Inguinal hernia, Curr Probl Surg 1991;28(6):401-50.

11. Rosemar $A$, Angerås $U$, Rosengren $A$. Body mass index and groin hernia: a 34-year follow-up study in Swedish men. Ann Surg. 2008:247(6):1064-8
12. Alfieri S, Rotondi F, Di Giorgio A, Fumagalli U, Salzano A, Di Miceli $D$, et al. Influence of preservation versus division of ilioinguinal iliohypogastric, and genital nerves during open mesh herniorrhaphy: prospective multicentric study of chronic pain. Ann Surg. 2006:243(4):553-8.

13. Wijsmuller AR, Lange JF, Kleinrensink GJ, van Geldere D, Simons MP, Huygen FJ, et al. Nerve-identifying inguinal hernia repair: a surgical anatomical study. World J Surg. 2007;31(2):414-20; discussion 421-2

14. Ergül Z, Kulaço $\square$ lu H, Sen T, Esmer AF, Güller M, Güneri $G$, et al. A short postgraduate anatomy course may improve the junior surgical residents' anatomy knowledge for the nerves of the inguinal region. Chirurgia. 2011;106(5):599-603.

15. Mottin CC, Ramos RJ, Ramos MJ. Utilização do sistema prolene de hérnia (SPH) para o reparo de hérnias inguinais. Rev Col Bras Cir. 2011,38(1):24-7.

Received on 15/06/2014

Accepted for publication 18/08/2014

Conflict of interest: none.

Source of funding: none.

Address for correspondence:

João Vicente Machado Grossi

E-mail: jvicentegrossi@gmail.com 